\title{
Livelihood Analysis of the Char Dwellers Using Capital Asset Framework
}

\author{
M. A. Rahman ${ }^{1 *}$ and M. A. Siddik ${ }^{2}$ \\ ${ }^{1}$ Department of Geomatics, Patuakhali Science and Technology University, Bangladesh \\ ${ }^{2}$ Department of Land Record and Transformation, Patuakhali Science and Technology University, \\ Bangladesh \\ *Corresponding author: ashiq.geo.bd@gmail.com
}

\begin{abstract}
The study has been carried out in a Riverine Island of the Ganges River in Chapai Nawabganj District of Bangladesh to evaluate the livelihood status and the association between different livelihood capitals and well-being status. Both qualitative and quantitative data are collected through household questionnaire survey and field observation. Most of the surveyed households are found either poor or hard core poor. This study identified five capitals of livelihood i.e. human, social, natural, financial and physical capitals with specific indicators. Family size and education indicators of human capital, organizational attachment of social capital, total and operational land of natural capital, value of livestock, size of savings and loan of financial capital and mobile phone of physical capital are statistically significant with the well-being status. This means higher value of indicators indicate higher the well-being status. Hence, this study assumes that most of the char dwellers are poor or hard core poor because their livelihood capitals and assets are not in satisfactory level. This study suggests providing necessary institutional and organizational supports for strengthening the livelihood of char dwellers.
\end{abstract}

Key words: Food security, Livelihood capital, Riverine island, Well-being status

\section{Introduction}

Bangladesh is a Riverine country and the largest delta of the world (Islam and Rashid, 2011). The natural setting of this country is between the Himalayas and the Bay of Bengal together with the prevalence of tropical monsoon climate (Rana and Nessa, 2017). The country is considered as the mercy of three major rivers i.e. the Ganges, the Bramaputra and the Meghna, altogether called as GBM basins (Bormudoi et al., 2011). The basins stretch over five countries like China, Nepal, India, Bhutan and Bangladesh (Mondal, 2011). They constitute about 1.65 million $\mathrm{km}^{2}$ catchment area of which only $7.5 \%$ lies within the territory of Bangladesh (Sarker et al., 2003).

Bangladesh is a country prone to flood and river bank erosion and natural disasters in the world (Lein, 2000; Siddik et al., 2018). The major rivers, GBM, carry huge volume of water every year in the country. In addition to that, they also carry about 1.1 billion tons of sediment per year (EGIS, 2000; Sarker et al., 2003). These two facets considered as the agents of flooding and river bank erosion in this well-known Riverine country (Elahi, 1991). The river inflow and rainfall contributes to the annual inundation of large areas of the country during the monsoon. In the active flood plains, the main rivers are constantly changing courses, leading to both riverbank erosion and accretion of new land (Haque and Zaman, 1989; Lein, 2000). The rivers not only erode land and causing settlements to be frequently on the move, but also throw up new virgin lands through accretion for newer settlements and agricultural activity (Baqee, 1997). These newly formed lands are called char in Bengali language. It comprises about 6.5 million populations in Bangladesh and constitutes almost five $\%$ of the total land area of the country which is about 7.2 thousand $\mathrm{km}^{2}$. (EGIS, 2000; Islam et al., 2006). These accreted lands are used by the people of both banks as their new settlement edges (Zaman, 1988; Baqee, 1993; 1998; Schmuck, 2001). In one hand, the char landscapes are of great importance for its exceptional hydrogeological settings (Sarker, 2008). On the other hand, the physical characteristics and spatial location as well as the river morphology and the monsoon climate render the char lands highly vulnerable to natural disasters (Baqee, 1986; 1998). Especially, livelihood of the char dwellers is at great threat because of flooding created by the consequent deposition of sediments on the river bed as well as river bank erosion. They create enormous impacts on livelihood of char people by damaging and/or destroying houses, crops and reducing family income (Baqee, 1998; Islam and Rashid, 2011; Siddik et al., 2017).

Bangladesh is ranked as $147^{\text {th }}$ on the Human Development Index. About 63 million people of this country live below the extreme poverty line (UNDP, 
2017). The country also ranked as $67^{\text {th }}$ (out of 84 countries) on the Global Hunger Index with a rating of 24.7 and the score is considered as alarming by the indexôs developers (Barun et al., 2009). It is already mentioned that about 6.5 million people live in char areas and their well-being status is not well compared to other parts of the country (EGIS, 2000; Islam et al., 2006). The northwest area of Bangladesh is the entry point of many rivers coming from the Himalayan ranges. The Ganges-Padma is one of the potential rivers of the country which formed char lands in the river channels (Baqee, 1998; Sarker, 2008). It is a meandering river and highly affected by river bank erosion and accretion in the channel (Islam and Islam, 1985; Baqee, 1993; 1998; Sarker, 2008). The char areas of the Ganges-Padma River are undergoing quick hydro morphological changes due to natural and anthropogenic causes (Hofer, 2006).

A number of studies e.g. Adnan and Monsoor (1976); Elahi (1987, 1989, 1991); Ali (1980); Baqee (1993; 1997); Hasan et al. (1999); Mamun and Amin (1999); Rahman and Davis (2005); Islam et al. (2006); Kabir (2006); Paul (2006); Mondal (2008); Bayes and Hossain (2009); Saifullah (2010); Rahman and
Rahman (2011, 2012); Uddin and Rahman (2011); Islam (2012); Uddin and Basak (2012); Karim (2014); Mollah and Ferdaush (2015) and Rana and Nessa (2017) have been conducted their studies on marginal peopleôs livelihood and mostly on char dwellers in different parts of the country. But, the authors couldnâ found any research on the drastic char area of the Ganges-Padma River, particularly on the association between wellbeing status and livelihood. Hence, this study aims to assess the existing livelihood status of the char dwellers of Chapai Nawabganj District and examine the association between well-being status and different capitals of livelihood.

\section{Study area}

\section{Methodology}

Char Laxmipur of the Ganges River was purposively selected as the study area which comprises of 4, 5 and 6 number wards of Panka Union (lowest administrative unit of local government) under Shibganj Upazila (sub district) of Chapai Nawabganj District (Fig. 1). There are total 296 households in this char area (UISC, 2017).

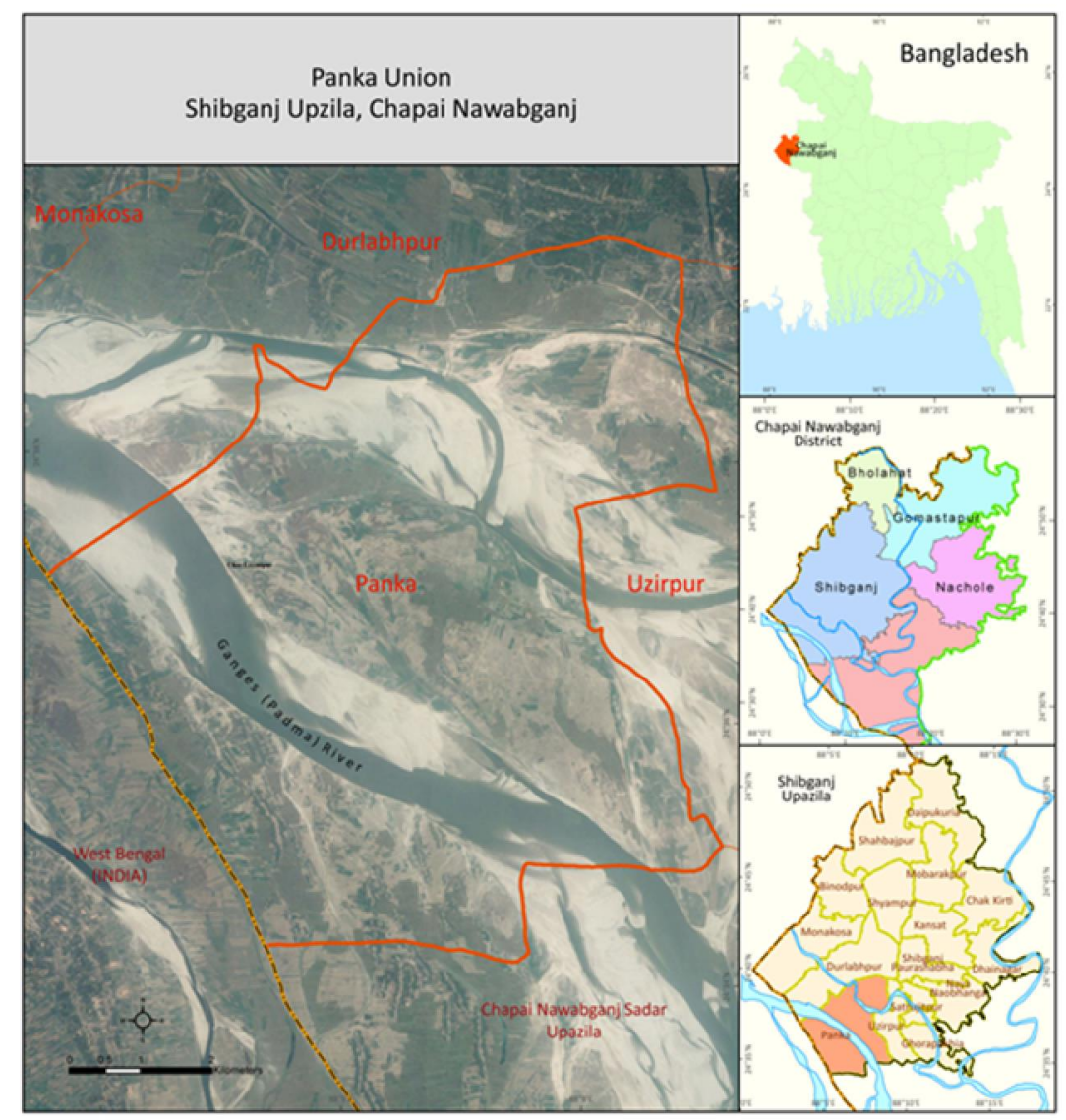

Fig. 1. Map showing the study area 


\section{Data collection and process}

Both quantitative and qualitative data were collected. Sample survey method was used to collect the primary data from the respective households. The main data collection techniques were direct observation and semi-structured questionnaire survey. Direct observation was done through transect walks. During transect walks, the researchers kept the objectives of the livelihoods study in mind. The dwellers took the opportunity to discuss their commonly felt problems and sought solutions with the researchers. The observation results were used in order to crosschecking the respondentsô answers during questionnaire survey. After completing direct observation, the semi-structured questionnaire survey was conducted with household representatives (both male and female) by means of face-to-face conversation. Due to time constraints and financial limitation, a total of 108 were chosen for conducting questionnaire survey from total 296 households by 93
$\%$ confidence level where the error was $7 \%$ with a 50

$\%$ response distribution. After that, a simple random sampling method was employed in order to carry out the survey in these sampled households. After inputting data into SPSS platform, if there were any items left out or any contradictory answers were found, then the respondents were revisited to obtain the missing and/or correct information. Secondary data is collected from published and unpublished documents. All the quantitative data was processed and analysed using SPSS Windows 20.0. Data was mostly presented in tabular and graphical form. The association between well-being status and livelihood was assessed using Gamma and Lambda analysis.

\section{Definition of well-being status}

The households were categorized as better off, middle class, poor and hard core poor (Table 1) based on daily income and food security (World Bank, 2004).

Table 1. Definition of well-Being status of the households based on World Bank, 2004

\begin{tabular}{lcl}
\hline \multicolumn{1}{c}{ Category } & $\begin{array}{c}\text { Per Capita Income } \\
\text { (USD) }\end{array}$ & \multicolumn{1}{c}{ Food Security (Daily) } \\
\hline Better off & $>4.0$ & Three meals \\
Middle class & $2.0-4.0$ & Three meals or less (seasonally food insecure) \\
Poor & $1.0-2.0$ & Two meals or less (moderately food insecure all the year \\
& & round) \\
Hard core poor & $<1.0$ & One meal or above (completely food insecure) \\
\hline Source: Paul, 2006 & &
\end{tabular}

\section{Capital asset framework (CAF)}

The level of economic status is a key indicator to assess the livelihood. Only a few successes have been achieved in eradicating rural poverty, although new ideas are developing and new approaches to rural development are being deliberated (Carney, 1998). Department for International Development (DFID) has been implemented a sustainable livelihood framework for reducing poverty since 1997. It is a crucial achieving the outcome of livelihood status using different assets and strategies. The framework is widely used in contemporary studies which not only for poverty eradication but also for socio-economic development and sustainable management of natural resources. Based on the assets (human, social, natural, financial and physical capital) included in the framework, a (CAF) is formulated for analysing the livelihood status of char dwellers in the study area (Fig. 2).

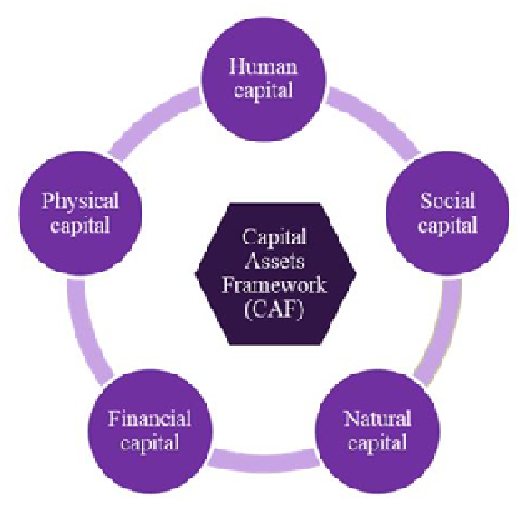

Fig. 2. Capital assets framework (CAF) 


\section{Results and Discussion}

\section{Well-being status}

Well-being status is an important indicator for identifying potential human resources. It is strongly interlinked with the occupation and income distribution and essential in describing livelihood strategy (DFID, 2001; Baumann, 2002). It has been determined based on the definition of daily income and food security set by World Bank (2004). According to the definition, only $4.6 \%$ of the surveyed households are found as middle class, $15.7 \%$ as poor and $79.6 \%$ hard core poor. Surprisingly there has not a single better-off household.

\section{Capital based livelihood status}

\section{Human capital}

Human capital may be the most important livelihood resource for the char dwellers. It encompasses labour, income capacity and household relation, education status, types of occupation etc. These parameters depend on the internal demographic factors of the family such as gender, age, marital status, family size etc. (Ellis, 2000). However, among the above mentioned determinants family size, earning source, education and number of earning person have purposively been selected to determine human capital in this study. It is found that the average family size is about 6.14, which is comparatively higher than the family size (4.59) at District level (BBS, 2015). The minimum and maximum value is 5 and 9 respectively whereas each family has 1 to 4 economically active family members (Table 2).

Table 2. Status of different human capital $(\mathrm{N}=108)$

\begin{tabular}{ccc|ccc}
\hline $\begin{array}{c}\text { Human } \\
\text { Capital }\end{array}$ & Statistics & Result & Human Capital & Statistics & $\%$ \\
\hline \multirow{3}{*}{ Family size } & & & & & \\
& Mean & 6.14 & & Day labour & 62.0 \\
& Median & 6.00 & Main earning & Farming & 29.6 \\
& Minimum & 5.00 & source & Business & 7.4 \\
& Maximum & 9.00 & & Service & 0.9 \\
\cline { 1 - 2 } Number of & Std. deviation & 0.971 & Education & Primary & 45.3 \\
earning & Mean & 1.84 & Junior secondary & 38.0 \\
person & Median & 2.00 & education among the & Secondary & 13.0 \\
& Minimum & 1.00 & family members) & Higher secondary & 3.7 \\
\hline
\end{tabular}

This study identified day labour, farming, business and service as the main income source of the surveyed families. Amongst them, day labour includes almost two-thirds of earning sources while business and service together hold a negligible portion (about 8.4 $\%)$. Educational status is believed as the important decision making parameter in a family. Among the surveyed households, about half of the familyôs highest level of education is primary education that means one to five classes whereas only $3.7 \%$ familyôs maximum education level is higher secondary (Table 2).

\section{Social capital}

Social capital is a broad term includes the norms and networks facilitating combined action for mutual benefits through the exchanges of experience, the sharing of knowledge and cooperation among rural livelihoods. It is now commonly agreed that social capital is crucial for enabling societies to prosper and achieve sustainability. The idea of social capital is closely associated to local institutions and collective effort. In rural and marginal society, conflict with relatives and neighbours is a common scenario which may arise due to unequal distribution of resources, making the opponent injured physically or mentally and some other underlying causes. Such conflict may cause the loss of property and weakening the social bonding. Hence, household with no conflict is may be a good sign for better livelihood status and considered as social capital in this study. The survey revealed that more than half of the respondents do not involved with any conflicts with their neighbours or relatives within last two years. In addition, conflict solving attitude is also considering as social capital. It is revealed that about $46.2 \%$ households showed their interest to solve such conflicts by social discussion (Fig. 3). 
Collective effort can save time and money. The char dwellers have carried out a few collective activities i.e. established mosque and village market, re-established school and relocated houses that have frequently been damaged due to river bank erosion. The survey result shows that only $26.9 \%$ of the respondents are directly involved in collective activities (Fig. 3).

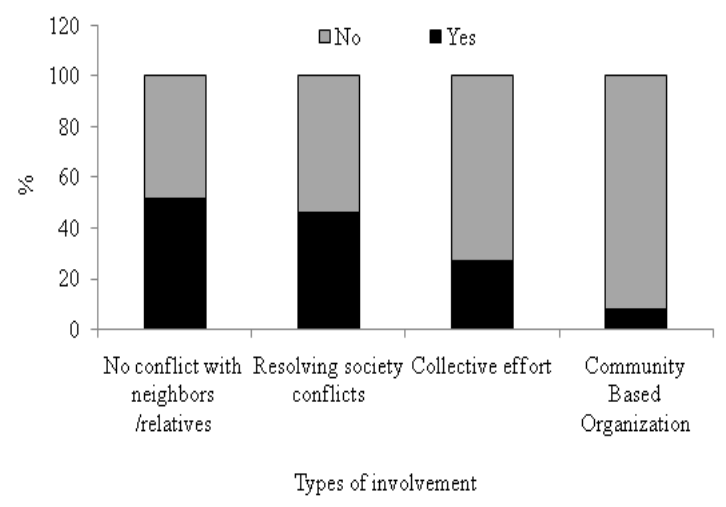

Fig. 3. Status of different social capital

Membership of local organization and/or participation in their different activities can be a good proxy of social capital because these may create opportunity to established network access to the developmental and social services. A few organizations are found in this remote area. However, levels of participation vary according to the well-being status of the household. Only $8.3 \%$ are identified as the member of such organizations (Fig. 3).

\section{Natural capital}

Natural capital represents the natural resources such as land, water and biological resources that are utilized to improve livelihood status. It is found during field observation that most of the dwellers have lost their homestead land due to river bank erosion. A huge amount of land is at riverbed. At present, a few amount of land is being used while most is fallow because of unstable char land. As a result, a noteworthy number of households are landless. The char dwellers stated during field observation that adjacent river is considered as the main source of supplying fish for their daily consumption. They opined that fish culture is quiet impossible in their premises or nearby area because most of the area are flooded during flood season.

Table 3. Status of different natural capitals

\begin{tabular}{ccc}
\hline Amount of land (decimal) & $\begin{array}{c}\text { Total land } \\
(\%)\end{array}$ & $\begin{array}{c}\text { Operational (agriculture) } \\
\text { land }(\%)\end{array}$ \\
\hline $\mathrm{N}$ & 108 & 72 \\
0 & 33.3 & 18.1 \\
$1-50$ & 47.2 & 54.2 \\
$51-100$ & 7.4 & 19.4 \\
$101-150$ & 5.6 & 5.6 \\
$150+$ & 6.5 & 2.8 \\
\hline
\end{tabular}

A person holding less than 50 decimals of land is defined as landless in Bangladesh (Abdullah and Murshid, 1986). Table 3 represents that about $33.3 \%$ families do not have any land and they live by taking lease from other dwellers. In addition, 47.2\% households have land ranges between 1-50 decimals. Hence, in total about $80.5 \%$ dwellers have 50 decimals or less land, are called as functionally landless. On an average each household (excluding no land group, $\mathrm{N}=72$ ) is holding 54.2 decimals land including minimum 8 decimals to maximum 300 decimals. In the context of operational land $(\mathrm{N}=72)$, about $18.1 \%$ households do not have any agriculture land. Each household (excluding no operational land group, $\mathrm{N}=59$ ) is holding average 51.9 decimals land including minimum 5 decimals to maximum 280 decimals.

\section{Financial capital}

Capital is the supply of accumulated goods committed to the production to which the household has access (Ellis, 2000). Financial capital facilitates the financing of working capital as well as long-term investment in fixed capital needs. In this study, the value of livestock, size of savings and loan are considered as the financial capital.

It is identified during informal discussion that most of the char dwellers used livestock resources as the recovery assistance after flooding in their area. They sell livestock for buying daily needs as well as cultivating land. They also use livestock for collecting and selling milk. This study explored that about $88.9 \%$ of households have livestock. The average market value of the livestock of each household is about 16,469 BDT including minimum $600 \mathrm{BDT}$ to maximum 86,200 BDT (Table 4). 
Table 4. Status of financial asset in BDT (Bangladeshi Taka)

\begin{tabular}{lccc}
\hline Statistics & Livestock value & Savings (last year) & Loan (last year) \\
\hline $\mathrm{N}$ & 96 & 31 & 47 \\
Mean & 16,469 & 9,758 & 9,809 \\
Median & 5,250 & 5,000 & 8,000 \\
Minimum & 600 & 2,000 & 3,000 \\
Maximum & 86,200 & 50,000 & 25,000 \\
Standard deviation & 22,959 & 12,487 & 5,445 \\
\hline
\end{tabular}

Savings is another decisive asset of financial capital which can create opportunity to cope with the different sorts of unusual occurrences. This study identified based on last year record that about $28.7 \%$ families have savings money ranges 2,000 to 50,000 BDT. In contrast, about $43.5 \%$ households have taken loan from their relatives or local moneylenders and the loan size is ranges 3,000 BDT to 25,000 BDT (Table 4). The organization credit system is totally absent because of geographical uncertainty.

\section{Physical capital}

Physical capital is an important means of accelerating growth in household incomes. Total ten assets have jointly been determined as physical capital of the respected households. These are sanitation system, drinking water system, power supply, radio player, television, bicycle, sewing machine, mobile phone, shallow pump machine and power tiller.

Fig. 4 shows presence of selected assets of physical capital in the surveyed households. It is explored that near about $90 \%$ of households have at least one mobile phone. This number is comparatively higher than the other assets because of low-price as well as prestigious indicator. In rural community of Bangladesh, other most effective social status indicators are personal sanitation, water supply and home lighting system. In the study area only $32 \%$ of households have own sanitation system and $28 \%$ have drinking water tube-well. In addition, about $28 \%$ have personal solar power based home lighting system and less than half of them have television. This study also found that only few $\%$ of households have bicycle, power tiller, radio player, shallow pump and sewing machine facilities.

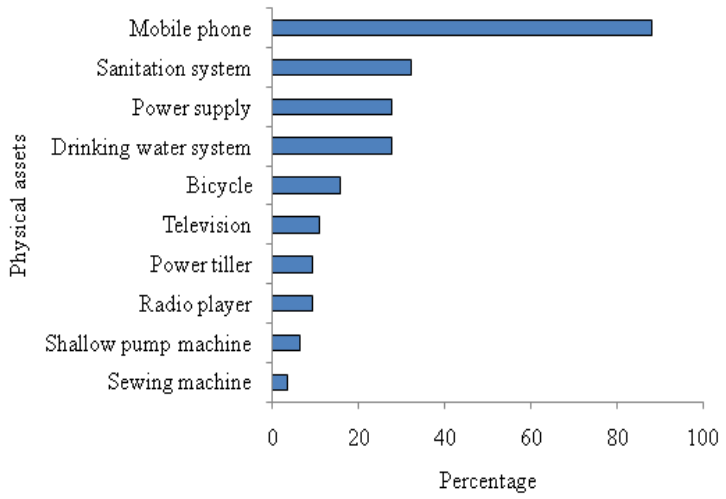

Fig. 4. Status of physical assets

\section{Association between livelihood capital and well-being status}

Household capital is important for the determination of well-being status of a family. Healthy status of household capitals plays a significant role of forming better well-being condition. The association between various parameters of five capitals namely human, social, natural, financial and political and well-being status are evaluated in the following sections.

Table 5. Association between household capital and well-being status

\begin{tabular}{rrrc}
\hline Capitals & Statistics & Value & Sig. \\
\hline (a) Human & & & \\
$-\quad$ Family size & Gamma & 0.468 & 0.013 \\
$-\quad$ Maximum year of schooling among the family & Gamma & 0.375 & 0.044 \\
$\quad$ members & & & \\
$-\quad$ Number of Earning Person & Gamma & -0.248 & 0.293 \\
$-\quad$ Earning Source & Lambda & 0.095 & 0.176 \\
\hline
\end{tabular}




\begin{tabular}{|c|c|c|c|}
\hline Capitals & Statistics & $\begin{array}{l}\text { Value } \\
\end{array}$ & Sig. \\
\hline \multicolumn{4}{|l|}{ (b) Social } \\
\hline - No conflict with neighbours /relatives & Lambda & 0.041 & 0.176 \\
\hline - Resolve conflict & Lambda & 0.056 & 0.477 \\
\hline - Collective Effort & Lambda & 0.057 & 0.176 \\
\hline - Member of local organization & Lambda & 0.258 & 0.009 \\
\hline \multicolumn{4}{|l|}{ (c) Natural } \\
\hline - Amount of family land & Gamma & 0.774 & 0.000 \\
\hline - Amount of operational land & Gamma & 0.839 & 0.000 \\
\hline \multicolumn{4}{|l|}{ (d) Financial (in BDT) } \\
\hline - Value of livestock & Gamma & 0.319 & 0.048 \\
\hline - Savings (last year) & Gamma & 0.609 & 0.009 \\
\hline - Size of loan & Gamma & -0.335 & 0.052 \\
\hline \multicolumn{4}{|l|}{ (e) Physical } \\
\hline - Sanitation system & Lambda & 0.137 & 0.029 \\
\hline - Drinking water system & Lambda & 0.187 & 0.002 \\
\hline - Power supply & Lambda & 0.088 & 0.197 \\
\hline - Radio player & Lambda & 0.031 & 0.654 \\
\hline - Television & Lambda & 0.147 & 0.162 \\
\hline - Bicycle & Lambda & 0.026 & 0.654 \\
\hline - Sewing machine & Lambda & 0.038 & 0.563 \\
\hline - Mobile phone & Lambda & 0.000 & $*$ \\
\hline - Shallow pump machine & Lambda & 0.207 & 0.153 \\
\hline - Power tiller & Lambda & 0.125 & 0.369 \\
\hline - Physical asset composite score & Gamma & 0.863 & 0.000 \\
\hline
\end{tabular}

*cannot be computed because the asymptotic standard error equals zero

Human capital is comprised of four indicators e.g. family size, education, number of earning person and earning source. It is considered as the important determinant of living condition and the welfare of family members. It is found from the results that the association between well-being status and family size as well as education is statistically significant ( $\mathrm{Sig}$. $<0.05)$ and the association level is moderate based on Gamma value $(<0.5)$. Therefore, it is understood that the higher the family size and education level indicates higher the wealth status. But, the association with number of economically active person of households is not statistically significant (Sig. >0.05). Moreover, insignificant relationship was also found between sources of income and wealth condition (Table 5).

Subsequently, the association between wealth condition and social capital such as no conflict with neighbour, participation in resolving social conflict and collective effort, and attachment with local social welfare organization, here also called as community based organization (CBO). Table 5 shows among the indicators of social capital, association of well-being status and attachment with $\mathrm{CBO}$ is found statistically significant (Sig. 0.009) but week (Lambda: 0.258). On the other hand, results do not demonstrate any significant relationship with the other parameters of social capital. After that, relationship between natural capital and wealth status was determined. It is already stated that two indicators are used identifying natural capital i.e. amount of family land and operational (agriculture) land. The Gamma value confirms that well-being status and family land is strongly associated (Gamma: 0.774, Sig. 0.000). This means the higher the well-being status, the higher the likelihood of possessing a large amount of land. Besides, the association with operational land is also found statistically significant (Gamma: 0.839, Sig. 0.000). Therefore, it seems that the higher the wealth status of a person, the greater the possibility of cultivable land (Table 5). Further, the relationship between wealth status and financial capital such as value of livestock, size of savings and loan was calculated. Results shows the association of all indicators of financial capital with well-being status is statistically significant (Sig. $<0.05$ ). The Gamma value indicates strongly associated with wealth condition than others (Table 5).

Likewise, association of well-being status and physical capital was identified. Table 5 presents that, among the 
physical assets only sanitation system and drinking water is statistically significant (Sig. <0.05) with wellbeing status. Afterward, a composite score for a household was computed by adding up scores given against the physical items where one household can get 1 (present) or 0 (absent) for each asset. Thus, a household can have maximum 10 composite score. The association between composite score of physical assets and well-being status is found statistically significant (Sig. 0.000) and the Gamma value 0.863 shows strong relationship (Table 5).

\section{Conclusions}

This study has been undertaken to assess the existing livelihood status of the char dwellers of the study area and analyse the relationship between their well-being status and different livelihood capitals. The result clearly shows that most of the char dwellers are either poor or hard core poor and they are functionally landless. Further, the study identified five capitals of livelihood to know their association with well-being status. They are (a) human capital include family size, earning source, education and number of earning person, (b) social capital comprises households with no conflict, conflict resolving attitude, collective effort and local organizational member, (c) natural capital consist of size of family land and operational land, (d) financial capital includes value of livestock, size of savings and loan, and (e) physical capital comprises ten household assets i.e. sanitation system, drinking water system, power supply, radio player, television, bicycle, sewing machine, mobile phone, shallow pump machine and power tiller. The association between these capitals and well-being status of the surveyed households has been analysed by Gamma and Lambda test. The result shows that family size and education of human capital are statistically significant at less than 0.05 levels. Likewise, organizational membership of social capital and family land as well as operational land of natural capital is significant at less than 0.01 levels. Similarly, value of livestock, size of savings and loan of financial capital are significantly associated with wealth status. Although most of assets of physical capital is not statistically significant but their composite score is significant and strongly associated with well-being status.

Overall, the status of livelihood (incorporated with different capitals) is not satisfactory and the association is somehow significant with the well-being status. This study suggests to ensure education facilities and effective family planning system, increase income generating options, ensure medical treatment, improve the activities of CBOs, provide low interest loan by initiating special programme and improve structural (embankment, road network and electricity supply) development in order to improving the livelihood status of the char dwellers of the study area. This research work done among the small number of population as well as in a small char area of Ganges River. In future, it is necessary to continue such research among the large group of people as well as in large char area.

\section{References}

Abdullah, A.A. and Murshid, K.A.S. 1986. Inter district changes and variations in landlessness in Bangladesh. The Bangladesh Development Studies, 14(3): 97-108. Retrieved from: https://www.jstor.org/stable/40795257

Adnan, S. and Monsoor, A.H. 1976. Land, power and violence in Barisal villages. Working Paper no. 6, Village Study Group. University of Dhaka, Dhaka.

Ali, S.M. 1980. Administration of char land in Bangladesh. Asian Affairs, 2: 295-303.

Baqee, A.H.M.A. 1986. Violence and agricultural seasonality in char-lands of Bangladesh, Oriental Geographer, 29\&30 (2): 25-36.

Baqee, A.H.M.A. 1993. The settlement process in the char-lands. Dissertation for the Doctoral Degree (unpublished). Department of Geography, University of Dhaka. Bangladesh. pp. 1-20.

Baqee, A.H.M.A. 1997. Coping with floods and erosion in Bangladesh char-lands. AsiaPacific Journal of Development, 4 (2): 38-52.

Baqee, A.H.M.A. 1998. Peopling in the land of Allah Jaane - power peopling and environment: the case of charlands of Bangladesh. The University Press Limited, Dhaka.

Barun, J., Hill, R.V. and Pandya-Lorch, R. (Eds) 2009. The poorest and hungry -assessments, analyses, and actions: an IFPRI 2020 book. International Food Policy Research Institute, Washington, D.C. Retrieved from: https://reliefweb.int/sites/reliefweb.int/files/re sources/25B0EA78AAC872B149257680001 F0E4A-ifpri-oct2009.pdf

Baumann, P. 2002. Improving access to natural resources for the rural poor: a critical analysis of central concepts and emerging trends from a sustainable livelihoods perspective. Food and Agriculture Organization (FAO). Retrieved from: http://www.fao.org/docrep/006/ad683e/ad683 e00.htm\#Contents

Bayes, A. and Hossain, M. 2009. Rural economy and livelihood. AH Development Publishing House, Dhaka. 
BBS. 2015. Bangladesh population and housing census 2011 zila report: Chapai Nawabganj. Statistics and Informatics Division, Ministry of Planning Government of the Peopleôs Republic of Bangladesh.

Bormudoi, A., Fowze, J.S.M., Hazarika, M.K., Samarakoon, L., Gunasekara, K., Kabir, S.M.H. and Mustofa, S.A. 2011. Rapid flood damage estimation: a case study at Chandpur, Bangladesh. In: Proceedings of $3^{\text {rd }}$ International Conference on Water and Flood Management, 8-10 January, Dhaka, 1: 283289.

Carney, D. (ed) 1998. Sustainable rural livelihoods: what contribution can we make? Papers presented at the Department for International Developmentôs (DFID), National Resources AdvisersôConference, July, London.

DFID. 2001. Poverty and the environment: what the poor say- an assessment of povertyenvironment linkages in participatory poverty assessments. Environment Policy Department, Issues Paper No. 1. London: Department for International Development.

EGIS. 2000. Riverine Chars in Bangladesh. The University Press Limited, Dhaka.

Elahi, K.M. 1987. Rural bastees and the phenomena of rural squatting due to riverbank erosion in Bangladesh. Seminar on Shelter for the Homeless. Urban Development Directorate, Dhaka.

Elahi, K.M. 1989. Population displacement due to riverbank erosion of the Jamuna in Bangladesh, In: J.I. Clarke, P. Curson, S.L. Kayastha and P. Nag (eds.), Population and Disasters. Basil Blackwell, Oxford, United Kingdom. pp. 81-97.

Elahi, K.M. 1991. Riverbank erosion, flood hazards and population displacement in Bangladesh, In: Elahi, K.M., Ahmed S.K., and Mofizuddin, M. (eds.), Riverbank Erosion Impact Studies. Graphosman, Jahangirnagar University, Dhaka. pp. 95-110.

Ellis, F. 2000. Rural livelihoods and diversity in developing countries. Oxford University Press, United Kingdom.

Haque, C.E. and Zaman, M. 1989. Coping with riverbank erosion hazard and displacement in Bangladesh: survival strategies and adjustments. Disasters, 13(4): 300-314. DOI: https://doi.org/10.1111/j.1467-

7717.1989.tb00724.x

Hasan, M., Haque, S.M. and Saroar, M.M. 1999. Responses and perceptions of people while coping with flood and riverbank erosion in
Bangladesh. Khulna University Studies, 1(2): 339-347. Retrieved from: http://ku.ac.bd/wpcontent/uploads/2016/12/V1-N2-P339347.pdf

Hofer, T.A. 2006. Floods in Bangladesh: history, dynamics and rethinking the role of the Himalyas. United Nations University Press, Tokyo. Retrieved from: https://collections.unu.edu/eserv/UNU:2465/p df9789280811216.pdf

Islam, F.M. and Rashid, A.N.M.B. 2011. Riverbank erosion displacees in Bangladesh: need for institutional response and policy intervention. Bangladesh Journal of Bioethics, 2(2): 4-9. DOI:

https://doi.org/10.3329/bioethics.v2i2.9540

Islam, M. and Islam, A. 1985. A brief account of bank erosion, model studies and bank protective works in Bangladesh. REIS Newspaper, 2: 1113.

Islam, M.N. 2012. Flood risks for the char community of the Ganges-Padma floodplain in Bangladesh. International Journal of Environment, 2(2): 106-116.

Islam, M.N., Islam, M.Z. and Akter, S.T. 2006. Bank erosion hazards of the Padma River at Zanjira- socioeconomic impacts. Indian Journal of Power and River Valley Development, 56 (3\&4): 123-130.

Kabir, R.D. 2006. The state of char education in Bangladesh: focus on selected chars of Gaibandha district. Asian Affairs, 28(3): 5-24. Retrieved from: http://citeseerx.ist.psu.edu/viewdoc/download ?doi=10.1.1.600.63\&rep=rep1\&type $=$ pdf

Karim, A.H.M.Z. 2014. Flood and riverbank erosion displacees: their indigenous survival strategies in two coastal villages in Bangladesh. Asian Social Science, 10(4): 1626. Retrieved from: http://www.ccsenet.org/journal/index.php/ass/ article/download/33786/19469

Lein, H. 2000. Hazards and forced migration in Bangladesh. Norsk Geografisk Tidsskrift Norwegian Journal of Geography, 54(3): 122-127.

DOI: https://doi.org/10.1080/002919500423735

Mamun, M.Z. and Amin, A.T.M.N. 1999. Densification: a strategic plan to mitigate riverbank erosion in Bangladesh. The University Press Limited, Dhaka.

Mollah, T.H. and Ferdaush, J. 2015. Riverbank erosion, population migration and rural vulnerability in Bangladesh (a case study on Kazipur upazila at Sirajgonj district). 
Environment and Ecology Research, 3(5): 125-131. DOI: 10.13189/eer.2015.030502

Mondal, G. 2008. Effects of land use changes on livelihood pattern of small farmers: a case study of Madertala village under Dumuria upazila in Khulna district. BRAC University Journal, 2: 93-99. Retrieved from: http://dspace.bracu.ac.bd/xmlui/bitstream/han dle/10361/437/Gautam.Mondal.pdf?sequence $=1 \&$ isAllowed $=\mathrm{y}$

Mondal, S.M. 2011. Review of regional water demand and resources in the Ganges-BrahmaputraMeghna basin. In: Proceedings of the 3rd International Conference on Water and Flood Management, Dhaka. 1: 359-370.

Paul, B.G. 2006. Household livelihoods analysis of char dwellers using the capital asset framework: the case of NRSP area, Jamalpur, Bangladesh. M.Sc. Thesis in International Studies in Aquatic Tropical Ecology, University of Bremen, Germany.

Rahman, M.A. and Rahman, M.M. 2011. Impact of livelihood practices on the char dwellers economic condition in riverine chars: case studies in Bangladesh. Journal of the Bangladesh Association of Young Researchers, 1(1): 15-30. DOI: https://doi.org/10.3329/jbayr.v1i1.6838

Rahman, M.A. and Rahman, M.M. 2012. Char formation process and livelihood characteristics of char dwellers of alluvial river in Bangladesh. In: 6th International Conference on Scour and Erosion, Paris. pp. 27-31.

Rahman, S. and Davis, J. 2005. A survey of rural livelihood and enterprise development opportunities in the chars, Bangladesh. Greenwich: DFID Poverty Oriented Research, Natural Resource Institute, University of Greenwich.

Rana, M.S. and Nessa, A.M. 2017. Impact of riverbank erosion on population migration and resettlement of Bangladesh. Science Journal of Applied Mathematics and Statistics, 5(2): 60-69. DOI: 10.11648/j.sjams.20170502.11

Saifullah, N.M. 2010. Char dwellersô adaptation to climate change. Unpublished Dissertation for the Degree of Master in Disaster Management. BRAC University, Dhaka, Bangladesh.
Sarker, M.H. 2008. Morphological response of the Brahmaputra-Padma-lower Meghna river system to the Assam earthquake of 1950 (pp. 1-296). Unpublished Doctoral Thesis. School of Geography, University of Nottingham, United Kingdom.

Sarker, M.H., Iffat, H. and Mustafa, A. 2003. Rivers, chars and char people of Bangladesh. International Journal of River Basin Management, 1(1): 61-80. DOI: 10.1080/15715124.2003.9635193

Schmuck, W.H. 2001. Facing the Jamuna River: indigenous and engineering knowledge in Bangladesh, pp. 10-242. Bangladesh Resource Centre for indigenous Knowledge (BARCIK). Bersha (Private) Limited, Dhaka.

Siddik, M.A., Akhtar, M.P. and Moniruzzaman, M. 2018. Cyclone Induced Land Transformation in the Bagerhat Coast of Bangladesh. International Journal of Innovative Research, 3(3): $68 \ddot{1} 72,2018$

Siddik, M.A., Zaman, A.K.M.M., Islam, M.R., Hridoy, S.K. and Akhtar, M.P. 2017. Socio-economic impacts of river bank erosion: a case study on coastal island of Bangladesh. The Journal of NOAMI, 34(2): 73-84.

Uddin A.F.M.A. and Basak, J.K. 2012. Effects of riverbank erosion on livelihood centre for research and action on development. Unnayan Onneshan- The Innovators, Dhaka.

Uddin, M.N. and Rahman, M.M. 2011. Socioeconomic impact of erosion along the right bank of the Jamuna River in Bangladesh. DUET Journal, 1(2): 35-42.

UISC. 2017. Union information service centre. Panka, Shibganj, Chapai Nawabganj.

UNDP. 2017. About Bangladesh: UNDP in Bangladesh. Retrieved from: http://www.bd.undp.org/content/bangladesh/e $\mathrm{n} /$ home/countryinfo.html

World Bank. 2004. The World Bank group millennium development goals. United Nations Millennium Goals. World Bank, Washington D.C. Retrieved from: www.developmentgoals.org/index.html

Zaman, M.Q. 1988. Joreï Jar-Jomi-Tar: a case reform in char land policies and administration in Bangladesh. In: River Bank Erosion Impact Study. Jahangirnagar University, Dhaka. 